\title{
P̈̈̈KKIRJOITUS
}

\section{TASA-ARVO TYÖELÄMÄN KOULUTUKSESSA}

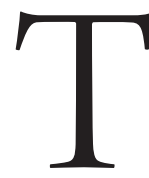

ASA-ARVO on aikuiskoulutuksen johtotähti. Valtiollisen aikuiskoulutuspolitiikan tasa-arvoajatus tiivistyy kahteen tavoitteekoko aikuisväestölle ja työmarkkinoilla pärjäämiseen liittyvien erojen pienentäminen. Työntekijöillä pitäisi olla tasa-arvoiset mahdollisuudet kehittää tietojaan ja taitojaan sukupuolesta, ammatista, luokka-asemasta, koulutustaustasta ja asuinpaikasta riippumatta. Toisaalta vähäisen koulutuksen vuoksi työmarkkinoilla huonosti pärjääville halutaan antaa "toinen mahdollisuus" parantaa omaa asemaa. Vähiten aikuiskoulutukseen osallistuvien väestöryhmien kouluttautumista on koetettu vuosien mittaan nostaa monin tavoin. Viime vuosien suurin julkisen vallan ponnistus on ollut Noste-ohjelma.

Työnantajan kustantama aikuiskoulutus eli henkilöstökoulutus on suurin ammatillisen aikuiskoulutuksen muoto Suomessa. Henkilöstökoulutukseen osallistuu vuosittain noin puolet palkansaajista, yli miljoona suomalaista. Siksi se on aikuiskoulutuksen tasa-arvon kannalta erittäin merkittävää. Työnantajat kouluttavat henkilöstöään oman henkilöstöpolitiikkansa mukaisesti, eikä siinä koulutuksen tasa-arvoinen jakautuminen ole ensisijaista. Miten koulutuksellista tasa-arvoa mitataan työelämässä, on monitulkintainen ja hyvinkin kiistanalainen asia. Onko se koulutuspäivien tasaista jakautumista henkilöstön kesken vai arvioidun koulutustarpeen mukaan? Ja miten koulutustarvetta mitataan? Vai onko tasa-arvoa tärkeämpää järjestää koulutusta niille, joiden kohdalla se tuottaa yritykselle suurimman hyödyn esimerkiksi lisääntyneenä tuottavuutena?

Perinteisesti henkilöstön kouluttaminen on ymmärretty työnantajien "yksityisasiaksi". Yritykset investoivat parhaiten tuottaviin kohteisiin, olkoot ne koneita, laitteita tai ihmisiä. Palkansaajapuoli ei mielellään jättäisi koulutusta vain yritysjohdon päätettäväksi. Viime vuosina osaamisen ylläpitäminen ja koulutuskysymykset ovatkin nousseet entistä vahvemmin palkansaaja- ja työnantajapuolen välisten työehtosopimusneuvottelujen asialistalle. Vuonna 2011 työmarkkinaosapuolet solmivat "raamisopimuksen", jonka mukaan työntekijöillä on oikeus kolmeen koulutuspäivään vuodessa. Sopimuksesta huolimatta sen toteutustavoista ja yksityiskohdista ei ollutkaan yksimielisyyttä. Tulkinnasta keskusteltiin vuosia. Työnantajapuoli ei pitänyt järkevänä säätä koko henkilöstöä koskevaa koulutusvelvoitetta. Palkansaajapuoli taas halusi koulutuksen jakautuvan tasaisemmin henkilöstön kesken.

Vuoden 2014 alusta voimaan tulleen lainsäädännön mukaan (SA 1136/2013) työnantajalla on velvollisuus huolehtia henkilöstön ammatillisen osaamisen kehittämisestä. Yritysten ja julkisorganisaatioiden on vuosittain laadittava tai päivitettävä kirjallinen henkilöstö- ja koulutussuunnitelma. Siihen on sisällyttävä (1) arvio koko henkilöstön ammatillisesta osaamisesta sekä ammatillisen osaamisen vaatimuksissa tapahtuvista muutoksista ja näiden syistä sekä (2) arvioon perustuva vuosittainen suunnitelma työntekijöiden 


\section{PERINTEISESTI HENKILÖSTÖN}

\section{KOULUTTAMINEN ON YMMÄRRETTY}

TYÖNANTAJIEN "YKSITYISASIAKSI".

ammatillisen osaamisen kehittämisestä henkilöstöryhmittäin tai muuten tarkoituksenmukaisella tavalla ryhmiteltynä.

Työnantaja saa koulutuskustannusten kattamiseen verovähennyksen tai sitä vastaavan taloudellisen kannusteen, koulutuskorvauksen. Verovähennyksen ja koulutuskorvauksen nettovaikutus on työnantajalle samansuuruinen. Työnantaja saa vuoden aikana tukea vähintään yhdeltä ja enintään kolmelta koulutuspäivältä työntekijää kohti. Verovähennyksen tai koulutuskorvauksen saaminen edellyttää koulutussuunnitelman lisäksi, että työntekijälle maksetaan koulutukseen osallistumisajalta palkkaa. Tavanomainen työhön perehdytys tai opastus ei oikeuta taloudelliseen tukeen.

Perusteluiden mukaan (HE 99/2013) uuden lainsäädännön tavoitteena olisi edistää työntekijöiden osaamisen kehittämistä, muutostilanteisiin varautumista ja työurien pidentymistä. Kun kiinnitetään huomiota työntekijöiden osaamisen tilaan ja kehittämistarpeisiin ja ryhdytään toimiin osaamisen kehittämiseksi, voidaan työn tuottavuutta ja Suomen kilpailukykyä parantaa. Osaamisen kehittämisen lähtökohtana olisivat liiketoiminnan ja julkispalvelujen tarpeet, mutta myös työntekijöiden pitkän aikavälin työllistymismahdollisuuksista huolehtiminen. Lain tavoitteena olisi ohjata ammatillisen osaamisen kehittämistoimia myös sellaisille työntekijäryhmille, jotka ovat jääneet vähemmälle koulutukselle. Osaamisen kehittämisestä ja sen kohdentamisesta voitaisiin päättää kunkin työpaikan tarpeista lähtien.

Lainsäädännöllä haetaan kompromissia yksityisen ja julkisen koulutuspolitiikan välille. Liiketoiminnan ja julkispalvelujen tarpeiden ohella työnantajan tulisi ottaa koulutustarjonnassa ja koulutuksen allokoinnissa huomioon työntekijöiden työmarkkinakapasiteetista huolehtiminen. Kun työnantajat perustavat henkilöstönsä kouluttamisen yksinomaan liiketaloudellisiin intresseihin, julkisen koulutuspolitiikan osaksi on jäänyt siitä aiheutuvien sosiaalisten eriarvoisuuksien kompensoiminen.

NIIN TYÖNANTAJA- KUIN TYÖNTEKIJÄPUOLIKIN varmasti kiinnostuksella seuraa, miten koulutussuunnitelmien laatiminen yleistyy. SAK:n lokakuussa 2014 luottamushenkilöille tekemän kyselyn ( $\mathrm{N}=953)$ mukaan lain voimaan tulon jälkeen vain joka kolmannella työpaikalla on aloitettu henkilöstö- ja koulutussuunnitelmien laatiminen. Suunnitelman laadintaan on ryhdytty useimmin julkisella sektorilla (51\%) ja suurimmilla työpaikoilla ( $55 \%$ ).

Työelämän koulutuksen tasa-arvoistumisen kannalta hyvää ei lupaa se, että vain alle kolmannes luottamushenkilöistä uskoo uuden lainsäädännön todella lisäävän työntekijöiden osallistumista koulutukseen.

Työelämän koulutusmahdollisuudet ja niiden jakautuminen ovat tärkeä yhteiskunnallinen kysymys. Määräaikaisillakin työntekijöillä olisi oltava mahdollisuus ammattitaitoa kehittävään koulutukseen - ja vieläpä sellaiseen, josta on hyötyä - ei vain yhdessä yrityksessä - vaan työelämässä laajemmin. Näin voitaisiin parantaa määräaikaisen tai muuten heikossa työmarkkina-asemassa olevan työntekijän mahdollisuuksia löytää itselleen uusi ja kenties parempi ja turvatumpi työ. Henkilöstön kouluttamisesta voi tulevaisuudessa tulla osa yritysten yhteiskuntavastuuta. Heikki Silvennoinen 